\title{
INVESTIGATION OF RISPERIDONE; CASE OF SELECTED PATIENTS FROM KENYA
}

\author{
Nnedinso Ohabuneyi ${ }^{1}$, Felix Ifeanyi Nwafor ${ }^{2}$
}

${ }^{1}$ School of Medicine, University of Nairobi, Kenya

${ }^{2}$ Nazareth Medical College, Kenya

*Corresponding Author: Nnedinso Ohabuneyi

Article Received: 11-06-19

Accepted: $30-10-19$

Published: 05-11-19

Licensing Details: Author retains the right of this article. The article is distributed under the terms of the $\begin{array}{lllll}\text { Creative } & \text { Commons } & \text { Attribution-NonCommercial } & 4.0 & \text { License }\end{array}$ (http://www.creativecommons.org/licences/by-nc/4.0/) which permits non-commercial use, reproduction and distribution of the work without further permission provided the original work is attributed as specified on the Journal open access page

\section{ABSTRACT}

Risperidone is considered as an atypical antipsychotic. It is considered as an effective treatment of psychotic disorders in adults. However, our understanding of its usage among young individuals is limited. In this study, the objective was to identify the safety profile of Risperidone among young children. Methodology wise, the study was conducted among children of less than 5 years old who were treating behavioral problems associated with various childhood disorders. The study was conducted in a hospital in Nairobi, Kenya. Common childhood disorders were diagnosed using the Diagnostic and Statistical Manual (DSM IV) and those associated with disruptive behavioral problems. We used Clinical Global Impression- Severity (CGI-S) and Improvement (CGI-I) scales for symptoms severity and improvement respectively. We took informed consents from parents of the children and initiated Risperidone. The total of 12 patients were included in the study consist of PDD (n=4), PDD plus ADHD (n=2), PDD plus ADHD plus Intellectual disability $(n=2)$, Cerebral Palsy with Epilepsy $(n=2)$ and Global developmental delay $(n=2)$. Baseline and end point CGI scores were 5-6 and 1-2 respectively. Baseline investigations such as lipid profile, fasting blood sugar levels, Electro cardiogram (ECG) were recorded and compared before and after initiation of risperidone. Dose range of risperidone was $0.5-2 \mathrm{mg}$ per day. Common side effects were sedation and weight gain in a few patients only. No lifethreatening side effects were noted. Our conclusion is that risperidone is well tolerated even in children below 5 years of age over a period of 1 year with improvement in target symptoms. 
Keywords: Young Children, Risperidone, Safety and Efficacy.

\section{INTRODUCTION}

Risperidone is a typical antipsychotic and its indications for usage among adults include acute case of mania in bipolar disorder, schizophrenia, persistent aggression, Alzheimer's disease, and conduct disorder. Previously, Risperidone was used for adults only, however, now it is started to use for youngsters such as age group of 5 years to 16 years especially after the approval of US FDA [1]. So far, it is found to be safe and effective among this age group. However, there is limited data available about administering it for youngsters less than 5 years of age.

\section{MATERIAL AND METHODS}

The study was based on a tertiary care hospital located in Nairobi, Kenya. The department of Psychiatry and Child neurology was the focus point of this study. All patients in this department were referred by outpatient department. We included those children who were diagnosed with Pervasive development disorder, ADHD, Intellectual disability, and Cerebral Palsy [2]. Common symptoms of these patients were out of control behavior, aggression, and irritability. We took informed consents from guardian/parents of these children whom we included in the study. Initially, we administered smaller dose and gradually increased its quantity. Side by side, we used Clinical Global Impression-severity (CGI-S) and improvement (CGI-I) [3] scales. We continued follows up for 4 weeks and continued assessed clinical improvement and side effects. For some cases, we continued follow up to 1 year. Other indicators including ECG, Lipid profile, fasting blood sugar, and base line weight were also monitored.

\section{RESULTS}

In this present study, there were total of 12 patients who were included in the study. Among these patients, 4 had pervasive developmental disorder; 2 had PDD plus attention deficit hyperactive disorder; 2 had PDD plus ADHD plus intellectual disability; 2 had Cerebral palsy with epilepsy; and 2 had Global developmental delay. Their baseline and end point CGI scores were 5-6 and 1-2 respectively. We started administering the risperidone dose from 0.25 to 0.5 mg. we gradually increased the dose in case of minimal or non-responsive to the lower doses. We administered dose increment among 10 patients out of total of 12 patients. We observed no side effects among 4 patients, and 2 patients showed abnormal weight gain. 
Table 1: Shows base line and final assessment of weight and Fasting blood sugar level along with demographic details

\begin{tabular}{|c|c|c|c|c|c|c|}
\hline Gender & $\begin{array}{l}\text { Age } \\
\text { in } \\
\text { Years }\end{array}$ & $\begin{array}{l}\text { Diagnosis } \\
\text { Results }\end{array}$ & $\begin{array}{l}\text { Weight - } \\
\text { Pre } \\
\text { Treatment }\end{array}$ & $\begin{array}{l}\text { Weight- } \\
\text { Post } \\
\text { Treatment }\end{array}$ & $\begin{array}{c}\text { FBS } \\
\text { baseline }\end{array}$ & $\begin{array}{c}\text { FBS } \\
\text { after 1 } \\
\text { year }\end{array}$ \\
\hline Male & 3 & $\begin{array}{l}\mathrm{CP} \text { with } \\
\text { Epilepsy }\end{array}$ & 10 & 12 & 88 & 90 \\
\hline Male & 5 & $\begin{array}{l}\text { CP with } \\
\text { Epilepsy }\end{array}$ & 12 & 13 & 76 & 87 \\
\hline Male & 4 & $\begin{array}{l}\text { CP with } \\
\text { Epilepsy }\end{array}$ & 13 & 14 & 69 & 76 \\
\hline Male & 4 & $\begin{array}{l}\text { CP with } \\
\text { Epilepsy }\end{array}$ & 14 & 15 & 70 & 75 \\
\hline Female & 3 & $\begin{array}{l}\text { PDD with } \\
\text { AHDD }\end{array}$ & 12 & 12 & 78 & 79 \\
\hline Male & 3 & $\begin{array}{l}\mathrm{CP} \text { with } \\
\text { Epilepsy }\end{array}$ & 12 & 12.50 & 89 & 82 \\
\hline Male & 4 & $\begin{array}{l}\text { PDD with } \\
\text { ADHD }\end{array}$ & 13 & 14 & 97 & 90 \\
\hline Male & 5 & $\begin{array}{l}\text { CP with } \\
\text { Epilepsy }\end{array}$ & 14 & 15 & 91 & 89 \\
\hline Female & 5 & $\begin{array}{l}\text { CP with } \\
\text { Epilepsy }\end{array}$ & 15 & 14 & 78 & 80 \\
\hline Male & 5 & $\begin{array}{l}\text { PDD with } \\
\text { AHDD }\end{array}$ & 15 & 15 & 70 & 89 \\
\hline Male & 4 & $\begin{array}{l}\text { PDD with } \\
\text { AHDD }\end{array}$ & 13 & 14 & 83 & 76 \\
\hline Male & 3 & $\begin{array}{l}\mathrm{CP} \text { with } \\
\text { Epilepsy }\end{array}$ & 12 & 12 & 85 & 89 \\
\hline
\end{tabular}

No patient included in our study showed severe side effects such as extra pyramidal side effects (EPS). We conducted other measures such as Lipid profile and fasting blood sugar and found no significant increase in base line levels. ormal fasting blood sugar levels were $<100 \mathrm{mg} / \mathrm{dl}$ and normal Total Cholesterol levels were $<300 \mathrm{mg} / \mathrm{dl}$ and normal Triglyceride levels $<150 \mathrm{mg} / \mathrm{dl}$.

Table-2: Shows base line and final lipid profile, CGI scores along with drug side effects

\begin{tabular}{|c|c|c|c|c|c|c|c|c|}
\hline \multicolumn{2}{|c|}{$\begin{array}{l}\text { Lipid Profile } \\
\text { Baseline }\end{array}$} & \multicolumn{2}{|c|}{$\begin{array}{l}\text { Lipid Profile after } 1 \\
\text { Year }\end{array}$} & $\begin{array}{l}\text { Side } \\
\text { Effects } \\
\text { after } 4 \\
\text { Weeks }\end{array}$ & $\begin{array}{l}\text { Side } \\
\text { Effects } \\
\text { after } 6 \\
\text { Months }\end{array}$ & $\begin{array}{l}\text { Side } \\
\text { Effects } \\
\text { after 1 } \\
\text { Year }\end{array}$ & $\begin{array}{l}\text { CGI } \\
\text { Score }\end{array}$ & $\begin{array}{l}\text { CGI } \\
\text { Score } \\
\text { after } 1 \\
\text { Year }\end{array}$ \\
\hline $\mathrm{TC}$ & TG & $\mathrm{TC}$ & TG & $\begin{array}{l}\text { No } \\
\text { Effects }\end{array}$ & $\begin{array}{l}\text { No } \\
\text { Effects }\end{array}$ & $\begin{array}{l}\text { No } \\
\text { Effects }\end{array}$ & 6 & 2 \\
\hline 115 & 67 & 145 & 65 & Sedation & $\begin{array}{l}\text { Weight } \\
\text { Gain }\end{array}$ & $\begin{array}{l}\text { No } \\
\text { Effects }\end{array}$ & 6 & 2 \\
\hline
\end{tabular}




\begin{tabular}{|c|c|c|c|c|c|c|c|c|}
\hline 123 & 69 & 154 & 61 & $\begin{array}{l}\text { No } \\
\text { Effects }\end{array}$ & $\begin{array}{l}\text { No } \\
\text { Effects }\end{array}$ & $\begin{array}{l}\text { No } \\
\text { Effects }\end{array}$ & 6 & 2 \\
\hline 165 & 75 & 167 & 63 & $\begin{array}{l}\text { No } \\
\text { Effects }\end{array}$ & $\begin{array}{l}\text { No } \\
\text { Effects }\end{array}$ & $\begin{array}{l}\text { No } \\
\text { Effects }\end{array}$ & 5 & 1 \\
\hline 134 & 63 & 167 & 67 & $\begin{array}{l}\text { No } \\
\text { Effects }\end{array}$ & $\begin{array}{l}\text { No } \\
\text { Effects }\end{array}$ & $\begin{array}{l}\text { No } \\
\text { Effects }\end{array}$ & 5 & 1 \\
\hline 122 & 55 & 178 & 68 & Sedation & $\begin{array}{l}\text { Weight } \\
\text { Gain }\end{array}$ & $\begin{array}{l}\text { No } \\
\text { Effects }\end{array}$ & 6 & 1 \\
\hline 116 & 60 & 162 & 54 & Sedation & $\begin{array}{l}\text { No } \\
\text { Effects }\end{array}$ & $\begin{array}{l}\text { No } \\
\text { Effects }\end{array}$ & 5 & 2 \\
\hline 118 & 76 & 189 & 57 & $\begin{array}{l}\text { No } \\
\text { Effects }\end{array}$ & $\begin{array}{l}\text { No } \\
\text { Effects }\end{array}$ & $\begin{array}{l}\text { No } \\
\text { Effects }\end{array}$ & 6 & 2 \\
\hline 123 & 71 & 152 & 51 & $\begin{array}{l}\text { No } \\
\text { Effects }\end{array}$ & $\begin{array}{l}\text { No } \\
\text { Effects }\end{array}$ & $\begin{array}{l}\text { No } \\
\text { Effects }\end{array}$ & 6 & 1 \\
\hline 113 & 74 & 146 & 80 & Sedation & $\begin{array}{l}\text { Weight } \\
\text { Gain }\end{array}$ & $\begin{array}{l}\text { No } \\
\text { Effects }\end{array}$ & 6 & 1 \\
\hline 121 & 70 & 148 & 78 & $\begin{array}{l}\text { No } \\
\text { Effects }\end{array}$ & $\begin{array}{l}\text { No } \\
\text { Effects }\end{array}$ & $\begin{array}{l}\text { No } \\
\text { Effects }\end{array}$ & 5 & 2 \\
\hline 115 & 81 & 154 & 82 & $\begin{array}{l}\text { No } \\
\text { Effects }\end{array}$ & $\begin{array}{l}\text { No } \\
\text { Effects }\end{array}$ & $\begin{array}{l}\text { No } \\
\text { Effects }\end{array}$ & 5 & 2 \\
\hline 126 & 72 & 151 & 84 & $\begin{array}{l}\text { No } \\
\text { Effects }\end{array}$ & $\begin{array}{l}\text { No } \\
\text { Effects }\end{array}$ & $\begin{array}{l}\text { No } \\
\text { Effects }\end{array}$ & 6 & 1 \\
\hline
\end{tabular}

\section{Discussion}

Behavioral problems can lead to the developmental disorders and is a major problem these days. Common examples of behavioral problem include self-injurious behavior, hyperactivity, aggression, and irritability which are often associated with Pervasive developmental disorders, mental retardation, and ADHDs [4]. It is estimated that such behavior prevail among 4 to $9 \%$ of all children [5,6]. The problem is that these behavioral problems interfere with rehabilitative efforts and pose severe challenges to parents, relatives, and other stakeholders such as educators and society [7]. It is recommended that in situation where behavioral problems interfere with daily activities, parents/guardian should seek pharmacological intervention. Typical Antipsychotics like haloperidol are commonly utilized, however, there risk of unwanted extra pyramidal symptoms is quite high. Atypical antipsychotics score over typicals in these side effects. Risperidone is also a solution for treating behavioral symptoms among adults. Most studies about its results are conducted among adults, and there is no such data of administering it among children less than 5 years of age [8]. Common behavioral problems among children can also be treated using the Risperidone as reports shows that it can help in overcoming these behavioral problems [9]. Here, it is important to mention that besides the medicine, the psychosocial intervention should be given priority for treating children behavioral problems [10]. Psychopharmacological intervention is required if symptoms causes significant distress to parents and other related individuals [11]. Based on this study, we reported that Risperidone can be used to treat effectively the disruptive behavior among preschool children. Our findings are matching with other studies findings which also reports similar findings. For example, study showed that Risperidone can be used for treatment of aggressive behavior in preschool children 
[12]. Common diagnosis for which Risperidone is used includes disruptive behavior disorder, ADHD, ID, and PDD [10]. In our study, we administered the Risperidone among children who were less than 5 years of age. We found that among these children, the common side effects of the Risperidone are weight gain and sedation. Overall, we found that Risperidone can be used to treat behavioral problems along with other psycho-social support to children.

\section{CONCLUSION}

On study findings basis, our conclusion is that Risperidone is well tolerated among children below 5 years of age. We observed in improvement in targeted symptoms as observed by us and parents. The improvement is also associated with reduced family burden and improved quality of life.

\section{Limitations}

The study limitations included small sample size and hence we suggest a larger study in future which can be placebo-controlled investigation or double blind in nature.

\section{References}

1. Hannah, B., Sophie, M. (2009). Guidelines for the use of oral risperidone in the short-term management of severe behavioural disturbance in autistic children and adolescents (aged 5 to 18 years) Purpose. 1st edition. East London NHS Foundation Trust Medicines Committee. 2009. 2. American Psychiatric Association. (1994). Diagnostic and statistical manual of mental disorders. 4th ed. Washington DC: American Psychiatric Association.

3. Guy, W. (1976). ECDEU assessment Manual for Psychopharmacology. U.S. Department of Health, Education and Welfare. Rockville.

4. Valsamma, E., Gururaj, A.K. (2005). Risperidone Treatment in 12 Children with Developmental Disorders and Attention deficit Hyperactivity Disorder. Prime Care Companion. Journal of Clinical Psychiatry, 7, 221-224.

5. Campbell, M., Gonzalez, N.M., Silva, R.R. (1992). The pharmacological treatment of conduct disorders and rage outbursts. Psychiatric Clinics of North America, 15, 6985.

6. Scott, S. (1998). Aggressive behaviour in childhood. British Medical Journal, 316, 202-206.

7. James, T.M., James, M., Bhavik, S., Pegeen, C., Daniel, H.A., Michael, G.A. (2002). Risperidone in children with autism and serious behavioral problems. New England Journal of Medicine, 347, 314-320.

8. Roberto, C., Valeria, S. (2008). Risperidone in the treatment of behavioral disorders associated with autism in children and adolescents. Neuropsychiatric Disease and Treatment, 4, 723-730.

9. Kewley, G.D. (1999). Risperidone in comorbid ADHD and ODD/CD. Journal of the American Academy of Child and Adolescent Psychiatry, 38, 1327-1328.

10. Murat, C., Suleyman, S.Z., Mucahit, O. (2011). Risperidone Treatment in Preschool Children with Disruptive Behavior Disorders: A Chart Review Study. Bulletin of Clinical Psychopharmacology, 21, 33-41. 
11. Gleason, M.M., Egger, H.L., Emsile, G.J., Greenhill, L.L., Kowatch, R.A. (2008). Lieberman $\mathrm{AF}$ et al: Psychopharmacological treatment for very young children contexts and guidelines. Journal of the American Academy of Child and Adolescent Psychiatry, 46, 1532-1572.

12. Cesena, M., Gonzalez-Heydrich, J., Szigethy, E., Kohlenberg, T.M., DeMaso, D.R. (2002). A case series of eight aggressive young children treated with risperidone. Journal of Child and Adolescent Psychopharmacology, 12, 337-345. 